\title{
Manajemen Pendidikan Untuk Pembangunan Berkelanjutan Di Indonesia
}

\author{
Mahayanti Fitriandari ${ }^{1}$, Hendra Winata ${ }^{2}$ \\ mahayanti.fitriandari@gmail.com, winatahendra@student.ub.ac.id \\ ${ }^{1}$ Universitas Ngurah Rai, ${ }^{2}$ Universitas Brawijaya
}

\begin{abstract}
ABSTRAK
Pandemi Covid-19 menjadi suatu pendorong dalam perubahan tatanan kehidupan secara lebih frontal. Disrupsi merambah pada seluruh sendi kehidupan, demikian juga dengan bidang pendidikan. Manajemen Pendidikan perlu sebuah konsep baru yang dinamis untuk dapat dijadikan sebagai patokan dalam era disrupsi ini. Implementasi dari Manajemen Pendidikan dengan konsep pembangunan berkelanjutan telah jamak dilakukan di Indonesia. Setiap Instansi Pemerintah, baik Kementrian ataupun Lembaga sudah mulai menerapkan konsep ini. Bahkan ada beberapa perusahaan baik swasta ataupun BUMN yang sudah mewujudkan pola Manajemen Pendidikan untuk Pembangunan Berkelanjutan Pembangunan Berkelanjutan adalah teori Manajemen Pendidikan, Teori Lingkungan dan Teori Pembangunan Berkelanjutan itu sendiri. Selanjutnya implementasi dari Manajemen Pendidikan dengan konsep pembangunan berkelanjutan telah jamak dilakukan di Indonesia.

Kata Kunci: Pembangunan Berkelanjutan, Manajemen Pendidikan
\end{abstract}

\section{ABSTRCT}

The Covid-19 pandemic has become a driving force for more frontal changes in the order of life. Disruption penetrates all aspects of life, as well as in the field of education. Education Management needs a new dynamic concept to be used as a benchmark in this era of disruption. The implementation of Education Management with the concept of sustainable development has been commonplace in Indonesia. Every Government Agency, both Ministries and Institutions have started to implement this concept. In fact, there are several companies both private and BUMN that have embodied the Education Management pattern for Sustainable Development. Sustainable Development is the theory of Education Management, Environmental Theory and Sustainable Development Theory itself. Furthermore, the implementation of Education Management with the concept of sustainable development has been commonplace in Indonesia.

Keywords: Sustainable Development, Education Management

\section{PENDAHULUAN}

Pandemi Covid-19 menjadi suatu pendorong dalam perubahan tatanan kehidupan secara lebih frontal. Disrupsi merambah pada seluruh sendi kehidupan, demikian juga dengan bidang pendidikan. Manajemen Pendidikan perlu sebuah konsep baru yang dinamis untuk dapat dijadikan sebagai patokan dalam era disrupsi ini. Ada sebuah konsep dinamis yang dapat dijadikan pedoman, yaitu Pendidikan untuk 
Pembangunan Berkelanjutan. Tujuannya adalah agar semua negara di dunia ini, baik negara miskin, negara kaya, ataupun negara kelas menengah dapat mengambil langkahlangkah yang diperlukan guna meningkatkan kemakmuran dan sekaligus tetap menjadi sebagai penjaga bumi. Strategi meningkatkan pertumbuhan ekonomi sebagai salah satu proses dalam upaya memenuhi berbagai kebutuhan sosial, baik Pendidikan, Kesehatan, perlindungan sosial dan kesempatan kerja, dapat dilakukan dengan terus menerus serta memperhatikan pula pembenahan atas perubahan iklim dan lingkungan, pengentasan kemiskinan.

Education for Sustainable Development (ESD) merupakan suatu kaidah dinamis yang mencakup visi baru pembelajaran yang memiliki maksud untuk memberdayakan masyarakat dari seluruh umur mengemban tanggung jawab untuk menghasilkan serta merasakan masa depan yang berkepanjangan, hal ini dikemukakan oleh Surakusumah (2009). Konsep ESD berupaya penuh meningkatkan pemberdayaan masyarakat negeri sehingga memiliki kontribusi aktif dalam membentuk lingkungan yang positif dalam perubahan sosial, bermakna partisipatif serta pendekatan berorientasi pada aksi atau tindakan.

Penggunaan istilah pembangunan berkelanjutan, apabila kita telaah secara etimologis berasal dari dua suku kata, yaitu pembangunan dan keberlanjutan. Kata pertama, yaitu pembangunan, berasal dari dasar kata bangun. Kata bangun ini kemudian diberi awalan pe- dan akhiran -an. Ketika diberikan awalan dan akhiran tersebut, kata bangun memiliki makna membangun. (Depdiknas 2007: 103). Makna membangun sendiri adalah suatu usaha yang dilakukan pada saat ini dalam kerangka perbaikan atas kondisi masa kini dan lampau yang masih belum sesuai dengan cita-cita kehidupan manusia. Proses membangun tersebut dilakukan dalam rangka perbaikan agar proses membangun tersebut dapat dinikmati oleh generasi selanjutnya dalam konteks masa depan yang cerah. Sedangkan suku kata kedua, yaitu kata berkelanjutan berasal dari kata dasar lanjut. Kata dasar lanjut ini, kemudian mendapat awalan ber dan ke serta akhiran an. Makna dari kata yang telah diberikan awalan dan akhiran tersebut menjadi tidak selesai sampai di situ saja; ada rentetannya; bersambung, atau terus-menerus (Depdiknas 2007: 636). Sebenarnya kata berkelanjutan ini merupakan pengembangan lebih lanjut dari kata berlanjut, yang memiliki makna yang sama.

Konsep utama sistem pendidikan untuk pembangunan yang berkelanjutan adalah pada pemahaman dari setiap stakeholder yang terkait untuk selalu memperhatikan lingkungannya. Jadi setiap arah dan gerak yang dilakukan pasti akan selalu 
dikembalikan kepada pemahaman komprehensif atas lokasi yang menjadi tempat tinggalnya. Hak siswa sebagai sasaran dari ESD ini sangat diperhatikan agar mereka mampu mengembangkan dan mengevaluasi secara jernih dalam mewujudkan visi mereka, memberikan alternatif pilihan untuk masa depan yang berkelanjutan. Para siswa tersebut dituntut untuk bisa lebih berkolaborasi dalam mewujudkan visi tersebut. Di lain sisi, para guru dituntut juga untuk selalu bekerja sama dengan para stakeholder lainnya, menyelaraskan persepsi yang berkembang dengan menggunakan alat analitik dari berbagai sumber, agar tercapai proses membangun orang agar lebih peduli pada lingkungan. Dengan demikian, upaya paling penting yang harus dilakukan para guru adalah proses pemahaman mereka atas lingkungan sekitar, tempat yang mereka tinggali, komunitas yang ada, budaya yang berkembang serta faktor-faktor lainnya yang berpengaruh pada lingkungan. Para guru dan siswa dituntut juga untuk lebih peduli atas lingkungan tempat mereka tinggal sekaligus mengidentifikasi perbedaan nilai-nilai, arah dan tujuan yang tidak selaras. Kemudian mereka harus memahami dan mengidentifikasi masalahnya untuk dapat dicarikan solusi sehingga ESD dapat terlaksana dengan baik.

Konsep ESD dicetuskan saat Earth Summit di Rio De Janeiro, Brasil pada tahun 1992. Pada pertemuan tersebut, dibahas berbagai agenda masalah. Beberapa hal utama, yang kemudian dicatat, dan dikenal sebagai Agenda 21. Pada bagian ini mengidentifikasi empat tujuan utama dalam memulai sebuah konsep ESD (Agenda 21 Bab 36):

1. Mempromosikan dan mengembangkan pendidikan dasar yang masih menjadi masalah bagi keseluruhan orang, lebih-lebih anak perempuan dan orang dewasa yang tuna aksara. Pendidikan dasar hendaklah difokuskan pada penyampaian pengetahuan, keterampilan, perspektif, dan nilai-nilai untuk mendorong dan mendukung warga negara untuk menjalani kehidupan yang berkelanjutan. Jika hanya meningkatkan keterampilan literasi dan perhitungan dasar yang seperti selama ini diajarkan, masyarakat tidak akan mengalami pembangunan berkelanjutan yang signifikan.

2. Mereposisi semua tingkatan pendidikan untuk menangani pembangunan berkelanjutan: memikirkan kembali dan merevisi seluruh tingkat pendidikan dari TK (Taman kanak-kanak) hingga universitas untuk mencakup lebih banyak dan penddikan keberlanjutan terkait dengan masing-masing dari tiga bidang, yaitu masyarakat, lingkungan dan ekonomi. 
3. Meningkatkan pengertian dan kepekaan publik terhadap pembangunan berkelanjutan: diperlukan sekelompok orang yang memahami tujuan masyarakat berkelanjutan dan memiliki pengetahuan dan keterampilan untuk berkontribusi dalam mewujudkan tujuan masyarakat yang lebih berkelanjutan. Informasi pemungutan suara dan pengetahuan konsumen membantu komunitas dan pemerintah dalam mengambil tindakan berkelanjutan menuju masyarakat yang lebih berkelanjutan.

4. Seluruh lapisan profesi dapat berkontribusi pada pembangunan yang berkelanjutan di semua sektor, dari lokal, regional maupun nasional. Mengembangkan program atau seminar pelatihan khusus untuk memastikan bahwa seluruh lapisan ketenagakerjaan mempunyai ilmu dan keterampilan yang dibutuhkan untuk melaksanakan pekerjaan mereka secara berkelanjutan.

UU No. 32 tahun 2009, khususnya Pasal 1 ayat (3) tentang Perlindungan dan Pengelolaan Lingkungan Hidup, menegaskan: Pembangunan berkelanjutan adalah upaya sadar dan terencana yang memadukan aspek lingkungan hidup, sosial, dan ekonomi ke dalam strategi pembangunan untuk menjamin keutuhan lingkungan hidup serta keselamatan, kemampuan, kesejahteraan, dan mutu hidup generasi masa kini dan generasi masa depan. Konsep pembangunan berkelanjutan didasari kondisi bumi yang telah banyak berubah tanpa disadari oleh manusia. Pada akhir tahun 2000, populasi dunia diperkirakan mencapai \pm 6 miliar. Jika laju pertumbuhan penduduk dunia sekitar 2\% per tahun, diperkirakan akan melebihi 7,68 miliar pada akhir tahun 2014. Sehingga banyak orang yang membutuhkan jasa seperti tempat tinggal, pakaian, makanan, air, hiburan, dan lain-lain yang semuanya bersumber dari sumber daya alam.

\section{KAJIAN TEORI}

Era disrupsi merambah hampir seluruh lini kehidupan. Tidak terkecuali juga di bidang pendidikan. Ketika disrupsi ini terjadi maka setiap insan yang bergerak dalam dunia pendidikan harus bersiap diri. Guna lebih memahami terkait dengan Pembangunan Berkelanjutan ini, maka ada beberapa teori yang bisa menjadi landasan berpikir, yaitu: Teori Manajemen Pendidikan, Teori Lingkungan dan Teori Pembangunan Berkelanjutan.

\section{Teori Manajemen Pendidikan}

Manajemen Pendidikan pada dasarnya memadukan seluruh sumber daya yang 
ada, baik dari personil, materiil dan sumber daya lainnya guna mencapai tujuan Pendidikan yang telah ditentukan pada periode tertentu. Tujuan Pendidikan biasanya telah ditentukan sebelumnya oleh sekelompok orang tertentu berdasarkan kesepakatan. Sumber daya yang ada akan dipergunakan secara efektif dan efisien secara produktif untuk menghasilkan suasana yang kondusif bagi orang-orang yang tergabung di dalamnya agar tujuan yang telah disepakai bersama tersebut dapat tercapai (Daulay, 2016).

Selanjutnya perkembangan manajemen Pendidikan di Indonesia berproses sesuai dengan perkembangan zaman. Manajemen Pendidikan pun mulai semakin beragam dengan perpaduan bumbu ilmu dari masa lampau yang termaktub dalam kitab-kitab suci sampai ilmu terkini mengenai psikologi manusia seraca pribadi, atau penerapan perkembangan kepribadian masing-masing anak didik. CBSA (Cara Belajar Siswa Aktif) sampai KBK (Kurikulum Berbasis Kompetensi). Kitab Kuning sampai e-book, klasikal sampai kelas alam. Pola pendidikan dengan disiplin yang sangat ketat (rambut cepak, berseragam) sampai pola Pendidikan yang sangat menjanjikan kebebasan (rambut gondrong, baju bebas). Semuanya diramu dengan satu tujuan, untuk mengembangkan pola pikir dan pengembangan transfer ilmu agar mampu menjadikan logika anak manusia lebih memahami makna yang ada di dunia ini.

\section{Teori Lingkungan}

Dengan jumlah kendaraan bermotor yang tidak sedikit dan berbagai pabrik yang beroperasi, lingkungan perkotaan umumnya lingkungan yang tercemar, yang terutama disebabkan oleh limbah industri dan asap yang dikeluarkan oleh kendaraan bermotor. Sebaliknya, di pedesaan banyak ditemukan lingkungan alami, dikarenakan kehidupan masyarakat yang masih sederhana dan sedikitnya kendaraan bermotor.

Lingkungan merupakan gabungan dari kondisi fisiografis yang meliputi air, tanah beserta mineral mineralnya, panas matahari, bersama dengan hewan dan tumbuhan, serta berbagai institusi ciptaan manusia yang mengatur tata cara memanfaatkan kekayaan alam tersebut. Semua yang ada di sekitar manusia, termasuk didalamnya komponen biologis dan non-biologis, disebut lingkungan (Dwiyatmo, 2007). Tempat dimana kita hidup, tumbuh, berkembang, dan mati, disebut lingkungan hidup.

\section{Teori Pembangunan Berkelanjutan}


Laporan Brundtland pada tahun 1987 yang pertama kali mendefinisikan pembangunan berkelanjutan sebagai pembangunan yang memenuhi kebutuhan saat ini tanpa mengorbankan kemampuan generasi mendatang untuk memenuhi kebutuhan mereka (Bovar et al., 2008). Model dasar pembangunan berkelanjutan dianggap sebagai bentuk yang mencakup aspek sosial, ekonomi dan lingkungan (Johnston, 2007).

Pada Earth Summit di Rio de Janeiro tahun 1992, konsep pembangunan berkelanjutan dikemukakan yang berfokus terhadap kondisi lingkungan global. Konferensi ini merupakan kelanjutan dari Konferensi PBB tentang Human Environment. Pembangunan berkelanjutan menitikberatkan pada tiga pilar atau aspek pembangunan, yaitu ekonomi, sosial, dan lingkungan. Saat ini banyak negara di dunia mencoba menerapkan pembangunan berkelanjutan, termasuk Indonesia. Konsep ini dirumuskan pemerintah dalam mekanisme pembangunan Indonesia dengan mengemasnya ke dalam kegiatan-kegiatan yang mendukung pembangunan berkelanjutan.

Adapun definisi ahli pembangunan berkelanjutan berpendapat bahwa pembangunan berkelanjutan adalah mengoptimalkan proses pembangunan dimana memanfaatkan potensi dan kemampuan manusia yang dikoordinasikan dengan sumber daya alam (Yayasan SPES, 1992). Pembangunan berkelanjutan juga diartikan sebagai jenis pembangunan, dimana satu sisi mengacu pada pemanfaatan terbaik kekayaan alam dan potensi manusia, di sisi lain adalah menjaga keseimbangan optimal antara kebutuhan sumber daya yang saling bertentangan (Ignas Kleden dalam Yayasan SPES, 1992: 3).

Secara konsep, pembangunan berkelanjutan dapat dijelaskan menjadi transformasi bertahap dari asas hubungan antar manusia, politik dan ekonomi untuk meningkatkan kepastian masyarakat Indonesia dalam mewujudkan kepentingannya saat ini tanpa mengorbankan kemampuan generasi penerus (Wibawa, 1991:26). Pembangunan berkelanjutan adalah strategi pembangunan di mana pemanfaatan SDA dan SDM, potensi investasi, perkembangan IT dan transformasi kelembagaan dilakukan secara simultan dan seimbang, dimana harus mencermati potensi periode sekarang dan ketersediaan di masa mendatang untuk memenuhi hajat dan kepentingan masyarakat.

Tiada satupun makhluk hidup yang bisa hidup sendiri. Dalam kehidupan tumbuhan dan hewan, aspek lingkungan memainkan peran yang sangat fundamental, karena makhluk hidup saling menghormati. Seperti makhluk hidup lainnya, manusia sangat memerlukan lingkungan yang baik untuk kelangsungan hidup. Kita harus terus 
menerus membersihkan lingkungan agar lingkungan selalu bersih. Dengan bertambahnya jumlah penduduk dan aktivitas yang terus bertambahnya, lingkungan sebenarnya telah mengalami degradasi, dan kualitasnya menjadi semakin rendah. Kondisi ini umumnya terjadi di kawasan kota metropolitan dan di kawasan pusat-pusat industri. Pencemaran air dan udara adalah penyebab utama dari penurunan kualitas lingkungan ini (Dwiyatmo, 2007).

Manusia adalah homo ecologus yang artinya seorang manusia merupakan elemen yang tidak bisa dipisahkan dari sistem ekologi (Dwiyatmo, 2007). Insting manusia cenderung selalu memahami lingkungannya. Manusia sangat erat hubungannya dengan lingkungan. Di era orde baru, terlihat bahwa masyarakat Indonesia memiliki kepedulian lingkungan yang sangat tinggi. Hal ini dikarenakan kebijakan pemerintah tentang pembangunan berwawasan lingkungan disuarakan kepada seluruh kalangan masyarakat.

Pembangunan berwawasan lingkungan meliputi lingkungan alam, lingkungan fisik, dan kesadaran masyarakat yang dilandasi oleh pengetahuan dan wawasan dalam sikap dan perilakunya, guna mengupayakan keberlanjutan lingkungan.

\section{Implementasi Konsep Dalam Penelitian}

Implementasi dari Manajemen Pendidikan dengan konsep pembangunan berkelanjutan telah jamak dilakukan di Indonesia. Setiap Instansi Pemerintah, baik Kementrian ataupun Lembaga sudah mulai menerapkan konsep ini. Bahkan ada beberapa perusahaan baik swasta ataupun BUMN yang sudah mewujudkan pola Manajemen Pendidikan untuk Pembangunan Berkelanjutan. Dalam Studi Pustaka yang dilakukan bahkan tampak bahwa beberapa Lembaga Swadaya Masyarakat dan Perusahaan Perorangan mulai juga menerapkannya. Beberapa contoh penggunaan konsep yang diterapkan dalam implementasi akan dijelaskan pada bagian berikut.

Manajemen Pendidikan yang dilaksanakan di Pondok Pesantren Modern Selamat Kendal (PPMS Kendal), menggunakan pola pengajaran pada siswa dengan mengenalkan Education for Sustainable Development atau Pendidikan untuk Pembangunan Berkelanjutan. Konsep ini dikenalkan pada agenda 21 (Kolbasov, 1992). Pola Pendidikan yang dilaksanakan di PPMS Kendal tersebut diantaranya adalah: 1) mengenalkan pada siswa tentang penghijauan di sekitar PPMS Kendal, 2) Pelaksanaan Kebersihan ruangan kamar yang diterapkan dengan disiplin ketat, sehingga setiap ruang kamar yang ada dapat terjamin kebersihan dan kerapiannya, 3) Bangunan fisik di PPMS 
Kendal yang diatur sedemikian rupa sehingga dapat memanfaatkan kearifan alam dengan menjaga sirkulasi udara dengan baik dan sekaligus memanfaatkan cahaya alami secara maksimal. Pengkajian secara lebih mendalam tentang tumbuhnya motivasi ini berikut persepsi siswa didalamnya telah dilakukan secara komprehensif pada tahun 2012. Hasil dari penelitian tersebut menunjukkan bahwa seluruh pengasuh pondok pesantren dan siswa yang ada menerapkan satu konsep universal, yaitu akhlakul karimah. Dengan demikian PPMS Kendal memiliki nilai-nilai spiritual dari setiap siswa dan pengasuhnya dalam penerapan kehidupan sehari-hari berupa upaya hidup mandiri dengan selalu memperhatikan lingkungan dan social secara terus menerus dan berperan aktif dalam kehidupan berkelanjutan bagi generasi masa depan. (Ngabekti, 2012)

Dokumen yang disajikan oleh PT Pertamina Persero terkait dengan Tata Kelola Perusahaan Pertamina disebutkan dengan jelas terkait dengan edukasi kepada setiap insan di Pertamina untuk selalu memperhatikan lingkungan (Pertamina, 2015). Manajemen pendidikan Pengembangan usaha dan portofolio yang berwawasan lingkungan dan disajikan dalam bentuk master plan. Pada halaman 54, dalam dokumen tersebut, disajikan juga secara eksplisit mengenai perlindungan lingkungan. Ada 9 poin yang wajib dilaksanakan oleh setiap insan Pertamina dalam upayanya untuk menjaga kelestarian lingkungan disekitar area usaha dan lingkungan perusahaan. Beberapa hal yang dilakukan diantaranya adalah dengan: 1) menjaga kelestarian lingkungan, 2) mentaati peraturan perundang-undangan dan standar pengelolaan lingkungan, 3) menyediakan dan menjamin semua perlengkapan dan peralatan pengelolaan lingkungan, 4) melakukan penyesuaian dan perbaikan yang terus menerus, 5) melakukan tindakan yang bersifat promotif dan preventif untuk mengantisipasi keadaan darurat, 6) melakukan penyelidikan dan penyidikan terhadap pencemaran lingkungan yang terjadi, 7) membuat laporan atas setiap pencemaran lingkungan yang terjadi, 8) melakukan pemeriksaan, inspeksi dan evaluasi secara berkala terhadap semua sarana, 9) melakukan pelatihan penanggulangan pencemaran lingkungan.

Perusahaan lain yaitu PT Astra International, diterapkan pola Manajemen Pendidikan yang berwawasan lingkungan pula. Konsepnya bahkan diimplementasikan dalam bentuk Kepedulian Perusahaan (CSR) dengan membentuk Kampung Berseri PT Astra International. Di kampung ini diterapkan empat prinsip dasar, yaitu Pendidikan, Kesehatan, Pendampingan UKM dan Lingkungan. Sejak pola perencanaan, implementasi dan evaluasi yang dilakukan selalu melibatkan peran aktif dari perangkat desa dan penduduk desa. Hasilnya, dari 72 Kampung Berseri dapat diidentifikasi adanya 
peningkatan kualitas hidup masyarakat, utamanya di bidang ekonomi, Pendidikan dan lingkungan (Nurlatifa et al., 2020).

Penerapan konsep kelestarian lingkungan telah diterapkan di Desa Lempake, Kecamatan Samarinda Utara, Kota Samarinda (Zaini, 2015). Pembangunan sarana dan prasarana umum yang dilaksanakan oleh pemerintah di Desa Lempake belum merata, namun progresnya baik dan sudah banyak kemajuan yang signifikan. Selain itu, partisipasi masyarakat sangat diperlukan untuk mendorong pembangunan lingkungan agar pelaksanaannya dapat berjalan dengan lancar.

Tingkat kebersihan lingkungan Desa Lempake perlu ditingkatkan lagi, walaupun saat ini kondisi lingkungannya sudah cukup bersih. Untuk mencegah dan mengurangi permasalahan lingkungan, kesadaran dan kepedulian masyarakat menjadi faktor esensial, sehingga masyarakat tidak lagi menangggung dampak masalah lingkungan. Selain itu, kondisi jalan dan kawasan pemukiman yang tidak baik akan sangat mempengaruhi lingkungan.

Ketua RT di Desa Lempake mengadakan gotong-royong yang rutin dilakukan sebulan sekali dalam rangka membangun kepedulian sosial terhadap perlindungan lingkungan, ini menandakan kepedulian masyarakat terhadap lingkungan cukup baik. Kondisi lingkungan Desa Lempake sangat kondusif bagi kegiatan ekonomi. Kesempatan untuk bekerja di lingkungan sekitar juga sangat menjanjikan, hal ini terlihat dari banyaknya lahan yang belum dikelola. Pemanfaatan lingkungan sekitar desa sangat baik, dimana masyarakat yang sebagian besar sebagai petani dan buruh tani mengelola langsung lingkungan yang tersedia. Hal ini tentu menjadi nilai tambah dalam menumbuhkan perekonomian masyarakat dari lingkungan sekitar dengan keikutsertaan pemerintah melalui program pemberdayaan masyarakat.

Penggunaan konsep Pembangunan Kota Berkelanjutan mencakup Peran Tata Ruang Kota dalam Pembangunan Berkelanjutan. Kota yang nyaman bagi masyarakatnya ialah kota yang mengelola tata ruang kotanya dengan sistem pembangunan berkelanjutan. Dalam mengakses aspek ekonomi dan sosial budaya, tidak dibatasi bagi tiap-tiap masyarakat untuk memenuhi keperluan dasar dan kebutuhan sosialnya.

Alasan perbedaan tersebut adalah karena Jakarta telah mengadopsi perspektif pembangunan konvensional, yaitu berkembang hanya dengan lebih menitikberatkan pada aspek fisik dan ekonomi dalam konteks arsitektur tertentu. Sementara itu kota lainnya menggunakan pandangan pembangunan berkelanjutan dari beraneka ragam 
inovasinya untuk mendapatkan suasana kota yang lebih nyaman sebagai tempat bernafas manusia. Salah satu bentuk kebijakan publik yang sangat penting adalah rencana tata ruang (Budihardjo, 2006).

Selain itu, pembangunan berkelanjutan juga diterapkan pada pengelolaan dan pelestarian sumber daya alam Indonesia. Dalam TAP MPR NO. IV/MPR/1999 tentang GBHN 1999-2004, prinsip-prinsip pembangunan berkelanjutan mengenai pengelolaan sumber daya alam dan lingkungan hidup menjelaskan 8 konsep pembangunan berkelanjutan sebagai sebuah kebijakan. Namun, sejauh ini, berdasarkan pengalaman aktual, situasi yang terjadi adalah pengelolaan sumber daya alam tidak dapat dikendalikan, dan akibatnya adalah kerusakan lingkungan dan rusaknya perlindungan alam. Pernyataan ini mengungkapkan pengakuan dari pemerintah di negara kita, yaitu dalam pembangunan berkelanjutan, pengelolaan dan perlindungan sumber daya alam belum dilakukan. Hal yang sama terlihat pada pembukaan TAP IX / MPR / 2001 yang menyatakan bahwa selama ini pengelolaan pertanian dan sumber daya alam telah menyebabkan penurunan kualitas lingkungan, timpangnya tatanan pengendalian, dan penurunan kepemilikan, penggunaan dan pemanfaatannya menyebabkan berbagai konflik. Peraturan perundang-undangan tentang Agraria atau pengelolaan sumber daya alam tumpang tindih dan saling bertentangan

\section{HASIL DAN PEMBAHASAN}

\section{Peluang Penggunaan Konsep Lainnya dalam Penelitian}

Peluang lain dalam konsep pembangunan berkelanjutan juga dapat diterapkan pada beberapa hal lain yang terkait dengan pengelolaan energi dan ketahanan pangan. Perusahaan energi Indonesia harus menerapkan manajemen energi berkelanjutan. Mulailah menggunakan energi terbarukan dan cari penggunaan alternatif. Bahkan dalam jangka menengah mulai 1 September 2018, produk solar akan digantikan oleh B20, baik bersubsidi maupun non-subsidi. Kementerian ESDM meminta industri pertambangan untuk menggunakan biodiesel (B20) sebagai bahan bakar. Kebijakan ini diatur dengan Perpres Nomor 66 Tahun 2018 tentang Penghimpunan dan Penggunaan Dana Perkebunan Kelapa Sawit, yang selanjutnya diatur oleh Kementerian ESDM melalui Permen No. 41 Tahun 2018, yang secara mendasar mengatur tentang penyediaan dan pemanfaatan Bahan Bakar Nabati (BBN) jenis biodiesel dalam kerangka pembiayaan oleh Badan Pengelola Dana Perkebunan Kelapa Sawit.

Peluang lainnya adalah melalui ketahanan pangan, yang terkait dengan 
ketersediaan pangan dan kesiapan pangan. Apabila tidak kelaparan atau tidak terancam kelaparan, dikatakan rumah tangga tersebut memiliki ketahanan pangan. Ketahanan pangan adalah keadaan tercukupinya pangan bagi Negara hingga warganya dan kemampuan untuk menahan gejolak di masa depan karena berbagai aspek (seperti kekeringan, transportasi, ketidakstabilan bahan bakar, ketidakstabilan ekonomi, perang, d1l). Penilaian ketahanan pangan dibagi menjadi swasembada perorangan dan depedensi eksternal. Kendatipun negara berharap individu dapat mandiri untuk menghindari kerentanan gagalnya transportasi, Negara maju sangat sulit mencapai ini karena pekerjaan setiap warga sangat beragam, dan jika industrialisasi tidak dilakukan maka biaya produksi pangan juga ikut tinggi. Sebaliknya, jika perekonomian tidak mencukupi dan tingkat swasembada pribadi tinggi, negara akan rentan terhadap ketidakpastian produksi.

Seperti yang terjadi di India, kebijakan Negara mampu mempengaruhi akses masyarakat terhadap bahan pangan. Dewan Negara India menyepakati rencana subsidi 2/3 dari penduduk India.

Rancangan Undang-Undang Ketahanan Pangan menyarankan agar pangan menjadi hak warga negara dan akan memberi 800 juta penduduk miskin lima kilogram makanan murah per bulan. Organisasi Kesehatan Dunia (WHO) memaparkan 3 komponen utama ketahanan pangan, yaitu ketersediaan, keterjangkauan dan pemanfaatan pangan. Aspek ketersediaan pangan yaitu kemampuan untuk memiliki kebutuhan dasar. Aspek keterjangkauan pangan mengacu pada kemampuan memiliki sumber daya baik secara fisik maupun ekonomi untuk mendapat pangan yang bernutrisi. Aspek pemanfaatan pangan mengacu pada kemampuan menggunakan bahan pangan secara baik dan benar. FAO juga menambahkan komponen keempat, yaitu stability yang mengacu pada jangka panjang dari ketiga komponen tersebut.

\section{KESIMPULAN}

Konsep Pembangunan Berkelanjutan telah dikenal sejak lebih dari 1 dekade yang lalu. Penerapan konsep pembangunan menjadi sebuah hal yang mutlak dan harus dilaksanakan. Kegiatan pembangunan berkelanjutan akan menjamin ummat manusia tetap dapat hidup dengan nyaman di Planet Bumi ini. Teori yang dapat menjadi landasan berpikir dalam mengembangkan konsep Pembangunan Berkelanjutan adalah teori Manajemen Pendidikan, Teori Lingkungan dan Teori Pembangunan Berkelanjutan itu sendiri. Selanjutnya implementasi dari Manajemen Pendidikan dengan konsep 
pembangunan berkelanjutan telah jamak dilakukan di Indonesia.

Konsep dan Implementasi Pembangunan Berkelanjutan telah dilaksanakan di Indonesia. Bahkan Lembaga Tertinggi Negara (MPR) telah memasukkan hal ini dalam Ketetapan MPR-nya. Ketetapan MPR ini kemudian diterjemahkan oleh Pemerintah dengan memasukkan beberapa pokok kegiatan yag dikaitkan dengan Pembangunan Berkelanjutan, yaitu Peran Tata Ruang dalam Pembangunan Berkelanjutan dan dalam Pengelolaan dan Pelestarian Sumber Daya Alam di Indonesia. Konsep lainnya yang akan diterapkan adalah melalui ketahanan Energi dan Ketahanan Pangan. 


\section{DAFTAR PUSTAKA}

Budihardjo, E. (2006). Percikan Masalah Arsitektur Perumahan Perkotaan. Gadjah Mada University Press.

Daulay, S. S. (2016). Pengembangan Ilmu Manajemen Pendidikan. Widyaiswara Madya Pusdiklat Industri, 1-22.

Dwiyatmo, K. (2007). Pencemaran Lingkungan dan Penanganannya. PT. Citra Aji Parama.

Kolbasov, O. S. (1992). Agenda 21: UN Conference on Environment and Development. In Izvestiya - Akademiya Nauk, Seriya Geograficheskaya (Vol. 6, Issue June). https://doi.org/10.4135/9781412971867.n128

Ngabekti, S. (2012). Konsep Pendidikan untuk Pembangunan Berkelanjutan, Studi Kasus di Pondok Pesantren Modern Selamat, Kendal. UGM.

Nurlatifa, E., Komariah, K., \& Nugraha, A. R. (2020). Implementasi Corporate Social Responsibility Pt. Astra Internasional Melalui Program Lingkungan Kampung Berseri. Jurnal Signal, 8(2), 170. https://doi.org/10.33603/signal.v8i2.3230

Pertamina. (2015). Good Corporate Governance of Pertamina. https://doi.org/10.1002/9781119200987.ch13

Lisa Anderson1, Paul Hibbert2, Katy Mason3, and Christine Rivers4. 2018. Management Education in Turbulent Times. Journal of Management Education 118.

Abdurrahman, DR, SH, MH. 2003. Pembangunan Berkelanjutan dalam Pengelolaan Sumber Daya Alam Indonesia.Seminar Pembangunan Nasional VIII.

M. Zaini1, Agus Tri Darmawanto2. 2015. Implementasi Pembangunan Berkelanjutan Berwawasan Lingkungan Studi Pada Kelurahan Lempake Kecamatan Samarinda Utara Kota Samarinda. JIEP-Vol. 15, No 2 November 2015.

Ni Luh Putu Miarmi. 2018. Konsep Perijinan Berwawasan Lingkungan dalam Mewujudkan Pembangunan Berkelanjutan. Diakses tanggal 12 September 2018. http://download.portalgaruda.org/article.php? article $=151033 \& \mathrm{val}=944 \&$ title $=$ KO NSEP\%20PERIJINAN\%20BERWAWASAN\%20LINGKUNGAN\%20DALAM \%20MEWUJUDKAN\%20PEMBANGUNAN\%20BERKELANJUTAN

S Fatmawati. 2015. Penerapan Kebijakan Pembangunan Berkelanutan di Lingkungan Kampus (Studi Perbandingan Antara Kampus Tembalang Universitas Diponegoro dan Kampus Tertre Universitas Ternate. Diakses tanggal 12 September 2018. https://ejournal.undip.ac.id/index.php/pwk/article/download/17599/12540

Undang - Undang Nomor 32 Tahun 2009 tentang Perlindungan dan Pengelolaan Lingkungan hidup 